University of Wollongong

Research Online

Faculty of Engineering - Papers (Archive)

Faculty of Engineering and Information

Sciences

$1-1-2011$

\title{
Removal of micropollutants by membrane bioreactor under temperature variation
}

\author{
Faisal I. Hai \\ University of Wollongong, faisal@uow.edu.au \\ Karin Tessmer \\ University of Wollongong \\ Luong N. Nguyen \\ University of Wollongong, Inn909@uow.edu.au \\ Jinguo Kang \\ University of Wollongong, jkang@uow.edu.au \\ William E. Price \\ University of Wollongong, wprice@uow.edu.au
}

See next page for additional authors

Follow this and additional works at: https://ro.uow.edu.au/engpapers

Part of the Engineering Commons

https://ro.uow.edu.au/engpapers/1065

\section{Recommended Citation}

Hai, Faisal I.; Tessmer, Karin; Nguyen, Luong N.; Kang, Jinguo; Price, William E.; and Nghiem, Long: Removal of micropollutants by membrane bioreactor under temperature variation 2011, 144-151. https://ro.uow.edu.au/engpapers/1065 


\section{Authors}

Faisal I. Hai, Karin Tessmer, Luong N. Nguyen, Jinguo Kang, William E. Price, and Long Nghiem 


\title{
1 Removal of micropollutants by membrane bioreactor under 2 temperature variation
}

3

4

5

6

8

9

10

11

12

13

Revised version submitted to

Journal of Membrane Science

August 2011

\author{
Faisal I. Hai ${ }^{1}$, Karin Tessmer ${ }^{1}$, Luong N. Nguyen ${ }^{1}$, Jinguo Kang ${ }^{1,2}$, William E. Price ${ }^{2}$, \\ and Long D. Nghiem ${ }^{1, *}$ \\ ${ }^{1}$ Strategic Water Infrastructure Laboratory \\ School of Civil, Mining and Environmental Engineering \\ University of Wollongong, NSW 2522, Australia \\ ${ }^{2}$ Strategic Water Infrastructure Laboratory \\ School of Chemistry \\ University of Wollongong, NSW 2522, Australia
}

14

15 * Corresponding author: Long Duc Nghiem, Email: longn@uow.edu.au, Ph +61 242214590 


\section{Abstract}

17 The effects of controlled temperature variation in the range of $10-45^{\circ} \mathrm{C}$ were assessed in a 18 lab-scale MBR that treated synthetic municipal wastewater spiked with selected 19 micropollutants. The effects were evaluated with respect to total organic carbon (TOC) and 20 total nitrogen $(\mathrm{TN})$ removal, micropollutant removal, sludge growth, level of soluble 21 microbial products (SMP) in the mixed liquor and membrane fouling. Overall, the 22 temperature shifts caused high variation in the TOC and TN levels in the reactor supernatant, 23 however that in membrane-permeate was relatively more stable, substantiating the robustness 24 of the MBR process. Results regarding the removal of micropollutants at ambient 25 temperature $\left(20{ }^{\circ} \mathrm{C}\right)$ demonstrate an apparent correlation between hydrophobicity, chemical 26 structures and the removal of micropollutants. Temperature variation below and above $20{ }^{\circ} \mathrm{C}$, 27 especially the operation under $45{ }^{\circ} \mathrm{C}$ appeared to significantly influence the removal of 28 certain less hydrophobic (Log $\mathrm{D}<3.2)$ micropollutants possessing strong electron 29 withdrawing functional groups. The removal of most hydrophobic compounds ( $\log \mathrm{D}>3.2)$ 30 was stable under the temperature range of $10-35{ }^{\circ} \mathrm{C}$, however, deteriorated at $45{ }^{\circ} \mathrm{C}$. The 31 temperature shifts were also associated with higher levels of SMP in the mixed liquor which 32 appeared to trigger membrane fouling as evidenced by a rapid increase in transmembrane 33 pressure.

34 Keywords: micropollutants, membrane bioreactor (MBR), temperature, operating condition, 35 water recycling. 


\section{$37 \quad 1$ Introduction}

38 In recent years, the applications of membrane bioreactors (MBR) for the treatment of both

39 municipal and industrial wastewater have increased dramatically. In particular, MBR has

40 been recognized as a key treatment process to facilitate wastewater reclamation and water

41 recycling practice [1-2]. At the same time, the occurrence of micropollutants such as

42 pharmaceutically active compounds and endocrine disrupting chemicals in raw and treated

43 domestic wastewater has been identified as a significant environmental health concern [3].

44 Although most of these contaminants remain unregulated, there is a growing consensus

45 among the scientific community and water authorities regarding their optimized removal

46 during wastewater to protect public health and the environment. Not surprisingly, there has

47 been a significant scientific interest regarding the removal efficiency of micropollutants by

48 MBR treatment [4-9].

49 Previous studies have indicated significant variation in the removal of micropollutants by 50 MBR, ranging from near complete removal for some compounds (e.g. ibuprofen and 51 bezafibrate) to almost no removal for several others (e.g. carbamazepine and diclofenac) [5, 52 8-9]. The reasons for such variation are not yet fully understood. Recent studies, therefore, 53 have focused on elucidation of underlying principles of micropollutant removal in MBR and 54 formulation of strategies to enhance micropollutant removal [7, 10-11]. With the aim of 55 finding avenues to enhance micropollutant removal, the effect of operational parameters such 56 as hydraulic retention time, sludge retention time [9] and $\mathrm{pH}[8,12]$ on the removal 57 efficiency of micropollutant in MBR have been specifically targeted.

58 Temperature fluctuation in biological wastewater treatment processes can result from 59 seasonal or diurnal (e.g. in arid and semi arid areas) variations, and from the operation of 60 batch units in upstream industrial processes [13]. Because microbial growth and activity [14] 61 as well as solubility and other physicochemical properties of organics [4] are significantly 62 affected by temperature conditions, temperature variability have been related to deterioration 63 in bulk water quality parameters and system instability [4, 13]. The effects have been 64 dependent on the temperature stability and the magnitude of any fluctuations, and have been 65 linked to sludge deflocculation and decreased sludge metabolic activity. Nevertheless, 66 systematic studies on the effects of temperature variation on micropollutant removal in either 67 conventional activated sludge (CAS) process or MBR remain very scarce. Most of the 68 observations of variation of micropollutant removal with ambient temperature have been 
anecdotal and based on measurement of limited number of samples at full scale plants, and have been reported as relatively high effluent concentrations of certain micropollutants during low winter temperature or vice versa [15-16]. In addition to temperature, other factors like overall pollutant loading, precipitation and sunlight availability (important for photodegradation) can also influence the observed seasonal variations in effluent concentration; therefore in the absence of a controlled experimental design the effect of temperature cannot be accurately ascertained. It is also noteworthy that the few available studies [17-19] that have specifically investigated the effect of temperature on micropollutant removal by lab-scale biological reactors have been restricted to a temperature range of below $30{ }^{\circ} \mathrm{C}$. Information on micropollutant removal performance beyond these limits is important as municipal wastewater plants can experience higher levels of temperature. These include situations when high temperature industrial effluent is mixed with municipal wastewater or in the cases of arid and semi arid areas where the diurnal temperature during the summer can vary from 30 to $55{ }^{\circ} \mathrm{C}$ [20]. It is also important to note that temperature-dependent soluble microbial products (SMP) levels in the mixed liquor may have significant implications on floc structure, sludge settleability and potentially on membrane fouling [21]. However, to date there has been no comprehensive study to investigate simultaneously the potentially interrelated effects of temperature variation on the mixed liquor characteristics, bulk organics and micropollutants removal and membrane fouling.

This study aims to investigate the effects of controlled temperature transients on the performance of a lab-scale MBR. The effects of controlled temperature shifts $(20,10,20,35$ and $45{ }^{\circ} \mathrm{C}$, respectively) were assessed in terms of TOC and TN removal, micropollutant removal, sludge growth, level of SMP in the mixed liquor and membrane fouling. Special focus was given on the intricate relationship between physiochemical properties of the micropollutants and their removal by MBR during operation under normal ambient temperature $\left(20^{\circ} \mathrm{C}\right)$ as well as the potential deterioration due to temperature fluctuations.

\section{Materials and Methods}

\subsection{Model micropollutants and synthetic wastewater}

97 A set of 22 compounds representing four major groups of micropollutants, namely 98 pharmaceutically active compounds, pesticides, hormones and industrial chemicals were selected in this study. The selection of these model compounds was also based on their

Hai, F. I., Tessmer, K., Nguyen, L. N., Kang, J., Price, W. E. \& Nghiem, L. D. (2011). Removal of micropollutants by membrane bioreactor under temperature variation. Journal of Membrane Science, 383 (1-2), 144-151. 
100 widespread occurrence in domestic sewage and their diverse physicochemical properties (e.g. 101 hydrophobicity and molecular weight). The effective hydrophobicity of these compounds 102 varies significantly as reflected by their Log D values at $\mathrm{pH} 8$ (see Supplementary Table S1).

103 A combined stock solution was prepared in methanol, kept in a freezer and used within a 104 month. Once stable operation had been achieved (see section 2.2) micropollutants were 105 continuously introduced to the feed solution to achieve a concentration of approximately $5 \mu \mathrm{g}$

$106 \mathrm{~L}^{-1}$ of each selected compound. The actual measured concentration in the feed was somewhat 107 lower than that added, the exact value depending on the sensitivity of detection of the specific 108 compound (see section 2.3). However, periodic chemical analysis of the influent samples 109 confirmed the accuracy and consistency of this dosing process throughout the duration of the 110 experiment.

111 A synthetic wastewater as utilized in a previous study [7] was modified as mentioned below 112 to simulate medium strength municipal sewage. The concentrated synthetic wastewater was 113 prepared and stored in a refrigerator at $4^{\circ} \mathrm{C}$. It was then diluted with MilliQ water on a daily 114 basis to make up a feed solution containing glucose $\left(400 \mathrm{mgL}^{-1}\right)$, peptone $\left(100 \mathrm{mgL}^{-1}\right)$, urea $115\left(35 \mathrm{mgL}^{-1}, \mathrm{KH}_{2} \mathrm{PO}_{4}\left(17.5 \mathrm{mgL}^{-1}\right), \mathrm{MgSO}_{4}\left(17.5 \mathrm{mgL}^{-1}\right), \mathrm{FeSO}_{4}\left(10 \mathrm{mgL}^{-1}\right)\right.$, and sodium 116 acetate $\left(225 \mathrm{mgL}^{-1}\right)$.

\section{$117 \quad 2.2$ Laboratory-scale MBR system and operation protocol}

118 A laboratory scale MBR system was employed in this study. The system consisted of a glass 119 reactor with an active volume of 9 L, a continuous mixer, two air pumps, a pressure sensor, 120 and influent and effluent pumps. Two ZeeWeed-1 (ZW-1) hollow fiber ultrafiltration (0.04 $121 \mu \mathrm{m})$ membrane modules supplied by Zenon Environmental (Ontario, Canada) were 122 submerged into the reactor. Each module had an effective membrane surface area of 0.047 $123 \mathrm{~m}^{2}$. The membrane modules were operated under an average flux of $4.3 \mathrm{Lm}^{-2} \mathrm{~h}^{-1}$ on a 14 124 minute suction and 1 minute rest cycle to provide relaxation time to the membrane modules. 125 An electrical magnetic air pump (Heilea, model ACO 012) with a maximum air flow rate of $126150 \mathrm{~L} \mathrm{~min}^{-1}$ was used to aerate the MBR system via a diffuser located at the bottom of the 127 reactor. High temperature can have a significant impact on dissolved oxygen (DO) 128 concentration in the reactor. Therefore the DO concentration in the reactor was monitored 129 daily by a DO probe and kept constant at $2 \pm 1 \mathrm{mgL}^{-1}$ by controlling the air flow rate. In 130 addition a continuously operated mixer ensured homogeneous mixing of the liquor and 131 prevented the settling of biomass. A small air pump was also used to provide a constant air 
132 flow through the membrane modules to reduce fouling and cake formation. Transmembrane 133 pressure was continuously monitored using a high resolution pressure sensor $( \pm 0.1 \mathrm{kPa})$ 134 which was connected to a personal computer for data recording. A stainless steel heat 135 exchanging coil was connected to a temperature controlling unit (Neslab RTE 7, 136 Thermofisher Scientific, Australia) and directly submerged into the reactor to maintain the 137 mixed liquor temperature at the desired level. The mixed liquor $\mathrm{pH}$ was stable around $138 \quad 7.8 \pm 0.1$.

139 The MBR was seeded with activated sludge from another lab-scale MBR system which had 140 been in continuous operation for over 3 years [7]. The hydraulic retention time was set at 24 141 hours, corresponding to a permeate flux of $4.3 \mathrm{Lm}^{-2} \mathrm{~h}^{-1}$. Apart from the samples for mixed 142 liquor suspended solid (MLSS), mixed liquor volatile suspended solid (MLVSS) and 143 extracellular polymeric substance (EPS) analysis, no sludge was withdrawn from the MBR at 144 any stage of this study. The sludge retention time (SRT), taking into account the amount of 145 sludge withdrawn for MLSS, MLVSS and EPS samples, was approximately $630 \mathrm{~d}$. After an 146 initial start up period of two months under a temperature of $20.0 \pm 0.1^{\circ} \mathrm{C}$, stable operation of 147 the MBR in terms of TOC and TN removal had been achieved. At this point, micropollutants 148 were added to the synthetic wastewater and the operating temperature was regulated to 149 different set points of $20,10,20,35$ and $45{ }^{\circ} \mathrm{C}$, respectively. At the end of each phase the 150 MBR temperature was changed at a rate of $5{ }^{\circ} \mathrm{C}$ day $^{-1}$ to a new temperature set point (See 151 supplementary figure S2). The system was operated for two weeks at $45{ }^{\circ} \mathrm{C}$ and for three 152 weeks at all other set points. During the entire operation, all other operating parameters 153 remained the same. Micropollutant analysis (see section 2.3) on duplicate samples was 154 conducted at least once each week to monitor the removal efficiency. The membrane modules 155 were cleaned by ex-situ soaking and backwashing with $\mathrm{NaOCl}$ before the start of the 156 investigation with temperature shifts. Membrane cleaning was also conducted just before the 157 initiation of operation at $35^{\circ} \mathrm{C}$ and when the system was operated at $45^{\circ} \mathrm{C}$. Further details 158 regarding membrane cleaning will be discussed in section 3.3.

159 As mentioned earlier, diurnal or seasonal variation in bioreactor temperature can happen, and 160 this study was designed to capture the effect of such changes on MBR performance rather 161 than to report steady state removal performance under different temperatures, which would 162 require acclimatization of the biomass under specific temperatures [19]. Our experimental 163 design is in line with a previous study by Morgan-Sagastume and Allen [13].

Hai, F. I., Tessmer, K., Nguyen, L. N., Kang, J., Price, W. E. \& Nghiem, L. D. (2011). Removal of micropollutants by membrane bioreactor under temperature variation. Journal of Membrane Science, 383 (1-2), 144-151. 
165 The micropollutants in feed and permeate samples were extracted using $6 \mathrm{~mL} 200 \mathrm{mg}$ Oasis 166 HLB cartridges (Waters, Milford, MA, USA). The cartridges were pre-conditioned with $7 \mathrm{~mL}$ 167 dichloromethane and methanol $(1: 1, \mathrm{v} / \mathrm{v}), 7 \mathrm{~mL}$ methanol, and $7 \mathrm{~mL}$ reagent water 168 respectively. The feed and permeate samples $(500 \mathrm{~mL}$ each) were adjusted to $\mathrm{pH} 2-3$ and 169 then loaded onto the cartridges at a flow rate of $15 \mathrm{mLmin}^{-1}$. The cartridges were then rinsed 170 with $20 \mathrm{~mL}$ Milli-Q water and dried with a stream of nitrogen for $30 \mathrm{~min}$. The trace organic 171 compounds were eluted from the cartridges with $7 \mathrm{~mL}$ methanol followed by $7 \mathrm{~mL}$ 172 dichloromethane and methanol $(1: 1, \mathrm{v} / \mathrm{v})$ at a flow rate of $1-5 \mathrm{mLmin}^{-1}$, and the eluents were evaporated to dryness under a gentle stream of nitrogen in a water bath at $40{ }^{\circ} \mathrm{C}$. The extracted residues were then dissolved with $200 \mu \mathrm{L}$ methanol solution which contained $5 \mu \mathrm{g}$

175 bisphenol A- $\mathrm{d}_{16}$ and transferred into $1.5 \mathrm{~mL}$ vials, and further evaporated to dryness under a 176 gentle nitrogen stream. Finally, the dry residues in the vials were derivatized by addition of $100 \mu \mathrm{L}$ of BSTFA (1\% TMCS) plus $100 \mu \mathrm{L}$ of pyridine (dried with $\mathrm{KOH}$ solid), which were

178 then heated in a heating block at $60-70{ }^{\circ} \mathrm{C}$ for $30 \mathrm{~min}$. The derivatives were cooled to room temperature and subjected to GC-MS analysis.

180 Analyses of the micropollutants were conducted using a Shimadzu GC-MS QP5000 system, 181 equipped with a Shimadzu AOC 20i autosampler. A Phenomenex Zebron ZB-5 (5\% 182 diphenyl - 95\% dimethylpolysiloxane) capillary column $\left(30 \mathrm{~m} \times 0.25 \mathrm{~mm} \mathrm{ID}, \mathrm{d}_{\mathrm{f}}=0.25 \mu \mathrm{m}\right)$ 183 was used. Helium carrier gas was maintained at a constant flow rate of $1.3 \mathrm{~mL} \mathrm{~min}{ }^{-1}$. The GC 184 column temperature was programmed from $100{ }^{\circ} \mathrm{C}$ (initial equilibrium time $1 \mathrm{~min}$ ) to $175^{\circ} \mathrm{C}$ 185 via a ramp of $10^{\circ} \mathrm{Cmin}^{-1}$ and maintained $3 \mathrm{~min}, 175-210^{\circ} \mathrm{C}$ via a ramp of $30^{\circ} \mathrm{C}, 210-228$ $186{ }^{\circ} \mathrm{C}$ via a ramp of $2{ }^{\circ} \mathrm{Cmin}^{-1}, 228-260{ }^{\circ} \mathrm{C}$ via a ramp of $30{ }^{\circ} \mathrm{C}, 260-290{ }^{\circ} \mathrm{C}$ via a ramp of 3 $187{ }^{\circ} \mathrm{C} \min ^{-1}$ and maintained $3 \mathrm{~min}$. The injector port and the interface temperature were 188 maintained at $280^{\circ} \mathrm{C}$. Sample injection $(1 \mu \mathrm{L})$ was in splitless mode.

189 For qualitative analysis, MS full-scan mode from m/z, 50 - 600 was used, apart from the 190 mass spectrum, the relative retention times of each compound was used for confirmation of 191 the compound. Quantitative analysis was carried out using selected ion monitoring (SIM) 192 mode. For each compound, the most abundant and characteristic ions were selected for 193 quantitation. The selected ions of the analyzed compounds after silyl derivatization are in 194 agreement with those reported elsewhere [22-23].

Hai, F. I., Tessmer, K., Nguyen, L. N., Kang, J., Price, W. E. \& Nghiem, L. D. (2011). Removal of micropollutants by membrane bioreactor under temperature variation. Journal of Membrane Science, 383 (1-2), 144-151. 
195 Standard solutions of the analytes were prepared at 1, 10, 50, 100, 500 and $1000 \mathrm{ng} \mathrm{mL}^{-1}$, and

196 an internal instrument calibration was carried out with bisphenol A- $\mathrm{d}_{16}$ as internal standard.

197 The calibration curves for all the analytes had a correlation coefficient of 0.99 or better.

198 Detection limits were defined as the concentration of an analyte giving a signal to noise ( $\mathrm{s} / \mathrm{n})$

199 ratio greater than 3 (see Supplementary Table S3). The Limit of Reporting was determined

200 using an $\mathrm{s} / \mathrm{n}$ ratio of greater than 10.

201 Removal efficiency was calculated as $R=100 \times\left(1-\frac{C_{E f f}}{C_{I n f}}\right)$, where $\mathrm{C}_{\text {Inf }}$ and $\mathrm{C}_{\text {Eff }}$ are influent

202 and effluent (permeate) concentrations of the micropollutants, respectively. It is noteworthy

203 that complete degradation of an organic compound may follow different pathways and

204 undergo several steps. Therefore, the term removal here does not necessarily indicate

205 complete degradation of the trace organics, but rather a loss of the specific trace chemical

206 molecule, either by a chemical change or sorption to solid surfaces.

\subsection{Other analytical methods}

208 Total organic carbon (TOC) and total nitrogen (TN) were analyzed using a Shimadzu

$209 \mathrm{TOC} / \mathrm{TN}-\mathrm{V}_{\mathrm{CSH}}$ analyzer. TOC analysis was conducted in non-purgeable organic carbon

210 (NPOC) mode. Samples were kept at $4{ }^{\circ} \mathrm{C}$ until analyzed and calibrations were performed in

211 the range between 0 and $1000 \mathrm{mg} \mathrm{L}^{-1}$ and 0 to $100 \mathrm{mgL}^{-1}$ for TOC and $\mathrm{TN}$, respectively.

212 Mixed liquor samples taken from MBR were centrifuged (Allegra X-12R, Beckman Coulter,

213 USA) at $3270 \mathrm{~g}$ and the TOC and TN concentration in the supernatant was measured as an

214 indication of bioreactor performance (before membrane filtration). MLSS and MLVSS

215 contents in the MBR reactor were measured in accordance to the Standard Methods for the

216 Examination of Water and Wastewater [24]. The concentrations of EPS and soluble microbial

217 products (SMP) were determined by previously described methods [25]. pH was measured

218 using an Orion 4-Star Plus pH/conductivity meter.

\section{Results and discussion}

\section{$220 \quad 3.1 \quad$ TOC and TN removal}

221 Figure 1 depicts significant variation in the level of TOC and TN in the reactor supernatant 222 due to temperature variation below and over the initial acclimatization temperature $\left(20^{\circ} \mathrm{C}\right)$. It 223 is well known that most biological reactions are slower at low temperatures [19]. On the other

Hai, F. I., Tessmer, K., Nguyen, L. N., Kang, J., Price, W. E. \& Nghiem, L. D. (2011). Removal of micropollutants by membrane bioreactor under temperature variation. Journal of Membrane Science, 383 (1-2), 144-151. 
224 hand, the decay and lyses of bacteria under (near) thermophilic temperatures can heighten 225 soluble microbial products release and simultaneously hinder metabolic activity, thereby 226 increasing the concentration of soluble carbonaceous/nitrogenous compounds in the effluent. 227 In a previous study by Sundaresan et al., [26] for a stepwise decrease of temperature from 35 228 to $5{ }^{\circ} \mathrm{C}$ the chemical oxygen demand (COD) removal performance of a submerged bed 229 bioreactor treating domestic wastewater was stable up to $15{ }^{\circ} \mathrm{C}$, however, deteriorated 230 moderately at $10^{\circ} \mathrm{C}$ and significantly at $5^{\circ} \mathrm{C}$. Furthermore, Morgan-Sagastume et al., [13] 231 reported $20 \%$ deterioration in soluble COD removal by a laboratory scale sequencing batch 232 reactor treating pulp and paper mill effluent due to a rapid temperature change from 35 to 45 $233{ }^{\circ} \mathrm{C}$. The significant variation observed in supernatant TOC and TN concentration in our study 234 at temperatures below $\left(10{ }^{\circ} \mathrm{C}\right.$ ) and over $20^{\circ} \mathrm{C}$ (i.e. at 35 and $45^{\circ} \mathrm{C}$ ) is hence not surprising. Of 235 particular interest was the fact that despite the large fluctuations in supernatant TOC 236 concentration $\left(100 \pm 94 \mathrm{mg} \mathrm{L}^{-1}\right)$ the TOC concentration in the membrane permeate was 237 consistently low $\left(8 \pm 7 \mathrm{mg} \mathrm{L}^{-1}\right)$ and stable (Figure 1a). Our observation is in good agreement 238 with other available MBR studies which also report more stable and improved permeate 239 quality as compared to the reactor supernatant quality despite significant temperature shifts 240 [20-21], possibly due to the retention of suspended and macro-colloidal organics on the 241 membrane cake layer. Fractionation of the TOC comprising the cake layer over the 242 membrane by techniques such as liquid chromatography organic carbon detection (LC243 OCD) can provide detailed information on the type of substances retained on the membrane, 244 however, that is beyond the scope of this study. On the other hand, as expected, in the 245 absence of a denitrification zone within the MBR, the TN removal in our study was fairly 246 low. No biological removal of TN (supernatant concentration exceeding that of the feed) 247 during operation under $45^{\circ} \mathrm{C}$ can be attributed to the release of nitrogen due to disintegration 248 of biomass $[13,26]$ and also to decreased MLSS concentration (see section 3.3). 249 Furthermore, as compared to the case of TOC, not much reduction in the TN concentration in 250 permeate over the concentration in the supernatant was observed. Our observation is 251 consistent with that of Al-Amri et al., [20] who also reported that physical removal by 252 membrane filtration in MBR does not contribute to the removal of ammoniacal nitrogen as 253 much as it does for COD.

Hai, F. I., Tessmer, K., Nguyen, L. N., Kang, J., Price, W. E. \& Nghiem, L. D. (2011). Removal of micropollutants by membrane bioreactor under temperature variation. Journal of Membrane Science, 383 (1-2), 144-151. 


\subsection{Micropollutant removal}

$256 \quad 3.2 .1 \quad$ Removal at the temperature of initial acclimatization

257 The removal efficiency of the selected micropollutants at the ambient temperature $\left(20{ }^{\circ} \mathrm{C}\right)$

258 has been plotted in Figure 2. Tadkaew et al., [7] have recently demonstrated that the 259 classification of trace organics according to their intended use or origin can only be used to 260 qualitatively predict the removal efficiencies of compounds having similar molecular features 261 or physicochemical properties. In good agreement with the study by Tadkaew et al., [7], in 262 this study, 80 - 99\% removal of all four hormones and four alkyl phenolic surfactant and 263 industrial compounds (bisphenol A, 4-t-butyl phenol, 4-t-octyl phenol, and 4-n-phenol) were 264 observed. These results are also consistent with previously published data [4-5, 7-8]. It is 265 noteworthy that all the hormones and alkyl phenolic compounds possess significant 266 hydrophobicity and the members of these groups share similar molecular backbone structures 267 between them, which may, in part, explain the similarities of their removal efficiencies. On 268 the other hand, owing to the difference in the molecular structure, removal efficiencies of the 269 eleven pharmaceuticals and two pesticides (fenoprop and pentachlorophenol) tested varied 270 widely even within the same class of therapeutic compounds. Therefore further discussion on removal efficiency will be based on physicochemical properties.

272 Previous studies have suggested that removal of the very hydrophobic $(\log \mathrm{D}>3.2)$ 273 compounds is probably dominated by sorption to the activated sludge followed by subsequent 274 biodegradation in the reactor [7, 27]. Given the long sludge age in MBRs, the removal of 275 micropollutants. which adsorb readily to the activated sludge, can be significantly enhanced 276 and is usually high [7]. Similarly, we observed near-complete removal of all the compounds 277 possessing a $\log \mathrm{D}>3.2$ (Figure 2). According to a simple qualitative framework proposed 278 by Tadkaew et al., [7] for compounds possessing lower hydrophobicity, functional groups 279 play an important role in determining the extent of biodegradation and thus overall removal. 280 They suggested that compounds possessing only electron withdrawing groups (EWG) may 281 have removal efficiency below $20 \%$, and those containing only electron donating groups 282 (EDG) may show more than $70 \%$ removal, while the removal of the compounds containing 283 both EWG and EDG may vary significantly. As discussed below, our results comply largely 284 with the qualitative framework recently proposed [7].

Hai, F. I., Tessmer, K., Nguyen, L. N., Kang, J., Price, W. E. \& Nghiem, L. D. (2011). Removal of micropollutants by membrane bioreactor under temperature variation. Journal of Membrane Science, 383 (1-2), 144-151. 
285 In good agreement with the well-documented poor removal of the anti-depressant drugs carabamazepine and primidone [5], we observed less than $40 \%$ removal of these recalcitrant compounds. Notably carbamazepine contains a strong EWG (amide) while primidone contains in addition a weak EDG (methyl). Despite possessing amide in its structure, the presence of the strong EDG hydroxyl group has been noted as the reason of achieving excellent removal of the non-steroidal anti-inflammatory drug (NSAID) acetaminophen in other studies [6]. The reason of rather low (below $50 \%$ ) removal of acetaminophen in this study in comparison to several previous studies $[4,6,28]$ could not be explained clearly; nevertheless this observation affirms the notion that presence of an amide group contributes significant recalcitrance to compound structure. Over $90 \%$ removal of the antipruritic (antiitching) medication salicylic acid is in line with previous reports [29] and can be attributed to the presence of strong EDG hydroxyl group along with the weak EWG carboxylic groups. On the other hand, all the compounds containing the weak EWG (carboxylic group) —weak EDG

298 (methyl) combination, namely, the hypolipidemic agent gemfibrozil and the NSAIDs naproxen, ibuprofen and ketoprofen showed above $50 \%$ to above $90 \%$ removal. The relatively higher removal of ibuprofen and gemfibrozil may be attributed to their higher hydrophobicity. The observed removal efficiencies of these four compounds are also in line with the literature reports [28]. The low and highly variable removal of the nitroimidazole antibiotic metronidazole is in good agreement with the report of Beier et al. [30], and may be attributed to the presence of strong EWG nitro group in its structure.

No specific report on the removal of the halogenated herbicide fenoprop by CAS or MBR could be found. However in line with the recalcitrance of the phenoxy carboxylic acid herbicides to biological treatment processes [31], a rather poor removal of that compound was achieved in this study. The removal efficiency of the other halogenated compounds (diclofenac, pentachlorophenol and triclosan) was in line with literature reports [5, 32]. Hai et al. [10] have recently demonstrated a combined effect of halogen content (ratio of molecular weight of the chlorine atoms to that of the whole compound) and hydrophobicity on the removal of halogenated trace organics by MBR. They suggested that compared to halogen content alone the ratio of halogen content to $\log \mathrm{D}$, which incorporates two important

314 physico-chemical properties, is a comparatively better index for prediction of removal. 315 Although the set of halogenated compounds used in this study was not entirely the same as 316 that used in the previous study, the observed trend remained the same. For example, although 317 fenoprop (Halogen content $=0.39, \log \mathrm{D}=-0.13$ ) and triclosan (Halogen content $=0.37$, 
$318 \log \mathrm{D}=4.76$ ) possessed similar halogen contents, among the tested halogenated compounds,

319 they were removed with the lowest and the highest efficiency, respectively.

[Figure 2]

321 3.2.2 Removal during operation under controlled temperature variation

322 For the significantly hydrophobic ( $\log \mathrm{D}>3.2)$ phenolic and steroidal compounds, which 323 were removed with $>90 \%$ efficiency during operation under $20^{\circ} \mathrm{C}$, insignificant difference 324 in removal efficiency was observed in the temperature range of $10-35^{\circ} \mathrm{C}$ (Figure 3 ). Similar 325 observations have been reported in the literature. Suzuki et al. [33] reported negligible change 326 in adsorption and decomposition of estrone and estradiol during batch tests at a temperature 327 as low as $5{ }^{\circ} \mathrm{C}$. Zuehlke et al., [34] observed no seasonal variation in estradiol, estrone and 328 ehinylestradiol removal in real conventional activated sludge plant. Gabet-Giraud et al., [35] 329 also reported that estrone and $17 \beta$-estradiol removal under 10 and $20^{\circ} \mathrm{C}$ was similar. Suarez 330 et al., [17] observed that $17 \beta$-estradiol and $17 \alpha$-ethinylestradiol removal was not significantly 331 different at 16 and $26{ }^{\circ} \mathrm{C}$. Our results regarding the steroidal compounds removal are 332 consistent with the above reports. In contrast, Tanghe et al., [18] reported significant 333 deterioration in the removal capacity of nonylphenol by a laboratory activated sludge due to a 334 temperature shift from 28 to $10^{\circ} \mathrm{C}$, while we observed no apparent change in the range of 10$33535{ }^{\circ} \mathrm{C}$. This discrepancy could possibly be attributed to the fact that for these readily 336 biodegradable compounds, MBR, in comparison to the activated sludge process, can achieve 337 more stable removal due to quicker response to operational perturbations [15].

338 Except for a few compounds (e.g. triclosan, 17ß-estradiol acetate, 4-t-octylephenol) whose 339 removal remained stable, for all other hydrophobic compounds, significantly lower removal 340 efficiency was observed at $45^{\circ} \mathrm{C}$. The reduced removal efficiency of the micropollutants in 341 the near-thermophilic $\left(45^{\circ} \mathrm{C}\right)$ range corresponds well with the higher variability of the TOC 342 and TN removal performance in that regime in our study. Contradictory reports on the effect 343 of a thermophilic temperature regime on micropollutants removal during anaerobic digestion 344 of sludge can be found in the literature [36-37]. No reports on specifically micropollutant 345 removal under aerobic thermophilic conditions could be found. However, LaPara et al., [38] 346 reported that mesophilic biological treatment was superior in COD removal than a 347 thermophilic aerobic biological treatment for a pharmaceutical wastewater. They argued that 348 the predicted advantages of thermophilic treatment, such as, rapid biodegradation rates and 349 low growth yields without loss of physiological function were not valid in the system they Hai, F. I., Tessmer, K., Nguyen, L. N., Kang, J., Price, W. E. \& Nghiem, L. D. (2011). Removal of micropollutants by membrane bioreactor under temperature variation. Journal of Membrane Science, 383 (1-2), 144-151. 
350 studied. Sludge disintegration under thermophilic temperatures can cause release of 351 micropollutants from the sludge phase to the water phase, thereby increasing the 352 concentration in the effluent. In addition, in our study, the observed MLSS concentration 353 drop (see section 3.3) beyond $20^{\circ} \mathrm{C}$ may have been another reason of deteriorated removal 354 performance in the near-thermophilic regime. It is also interesting to note that sorption along 355 with biodegradation plays an important role in the overall removal of the significantly 356 hydrophobic compounds. For most compounds, equilibrium sorption decreases with 357 increasing temperature [39]. It is possible that hindered adsorption, sludge disintegration and 358 metabolic activity were simultaneously responsible for the lower removal of the significantly 359 hydrophobic compounds at $45^{\circ} \mathrm{C}$.

360 A similar trend of reduced removal at the near-thermophilic temperature of $45{ }^{\circ} \mathrm{C}$ was 361 observed in case of the less hydrophobic compounds $(\log \mathrm{D}<3.2)$, and can be explained 362 again by the disrupted metabolic activity typically associated with operation under such 363 elevated temperature. In addition, a comparatively more pronounced variation between 364 removals in the lower temperature regimes was observed. Comparing the removal 365 performance in summer and winter Sui et al., [15] suggested that for the easily biodegradable 366 compounds MBR performance can be expected to show less susceptibility to ambient 367 temperatures as compared to conventional activated sludge process. However, compounds, 368 which were moderately removed in MBR (e.g. diclofenac), showed seasonal variation. 369 Nevertheless, no removal was achieved regardless of the season or the treatment processes 370 for the recalcitrant micropollutants such as carbamazepine. A similar observation was also 371 reported by Castiglioni et al., [40]. Our results corroborate well with the trends reported in 372 literature. The compounds that are usually well removed by MBR (e.g. salicylic acid, 373 ibuprofen, gemfibrozil, pentachlorphenol and estriol) and exhibited a removal efficiency of 374 over $80 \%$ at $20^{\circ} \mathrm{C}$ in this study, showed negligible variation at 10 and $35{ }^{\circ} \mathrm{C}$. Lower and/or 375 more variable removal at $10{ }^{\circ} \mathrm{C}$ was observed for certain compounds (e.g. ketoprofen, 376 naproxen, metronidazole) which are reported to be moderately recalcitrant to MBR treatment $377[7,10]$. The removal of carbamazepine at $20^{\circ} \mathrm{C}$ in this study was originally low, nevertheless 378 higher than that reported in real plants $[5,15]$ and plummeted further both above and below 379 the temperature of initial acclimatization $\left(20^{\circ} \mathrm{C}\right)$, indicating the extreme sensitivity of this 380 recalcitrant compound removal to the operating conditions.

Hai, F. I., Tessmer, K., Nguyen, L. N., Kang, J., Price, W. E. \& Nghiem, L. D. (2011). Removal of micropollutants by membrane bioreactor under temperature variation. Journal of Membrane Science, 383 (1-2), 144-151. 
381 In the absence of relevant temperature-dependent removal efficiency related information in

382 the literature, it, however, remains unexplainable why the highest removal efficiency of 383 certain compounds were achieved at the two end values of temperature ranges tested i.e., at $38410{ }^{\circ} \mathrm{C}$ (primidone and diclofenac) and $45{ }^{\circ} \mathrm{C}$ (fenoprop and acetaminophen), respectively, 385 despite the fact that the sludge was originally acclimatized at $20{ }^{\circ} \mathrm{C}$. Nevertheless, it is noteworthy that except for acetaminophen, the other three compounds (fenoprop, primidone, and diclofenac), which exhibited rather unexpected behavior (Figure 3), have also been widely reported to show low and highly variable removal in MBR $[7,10]$.

It is noteworthy that this study aims to capture the effect of dynamic temperature transient conditions (e.g., diurnal variation) on micropollutant removal by MBR. The removal performance may be different if longer acclimatization period under each temperature regime is applied. However, that is beyond the scope of this study.

\subsection{Sludge characteristics and membrane fouling}

396 A significant impact of temperature on MLSS concentration was observed during operation at 35 and $45{ }^{\circ} \mathrm{C}$ (Figure 4). In this study, in the absence of sludge withdrawal, the MLSS concentration steadily rose for the first two months of operation under $10-20{ }^{\circ} \mathrm{C}$, however, rather sharply decreased to the initial level when the temperature was elevated beyond $20{ }^{\circ} \mathrm{C}$. Al-Amri et al., [20] reported a similar observation. They attributed the MLSS reduction at elevated temperatures of $35^{\circ} \mathrm{C}$ and $45{ }^{\circ} \mathrm{C}$ to the changes in ambient temperature experienced by the microorganisms (biomass shock). Dias et al., [41] hypothesized that at higher temperatures, the cells utilize a large fraction of the energy to maintain their vital functions and not only to synthesize new cellular material, hence, causing reduction in the biomass growth. While the MLVSS/MLSS ratio in this study remained stable, the lower level of MLSS during operation under 35 and $45^{\circ} \mathrm{C}$ can possibly suggest lower level of metabolism within the reactor, which may partially explain the lower level of removal of some micropollutants in the near thermophilic temperature regime.

\section{[Figure 4]}

410 EPS and SMP levels in the mixed liquor may have significant implications on floc structure,

411 sludge settleability and potentially on membrane fouling. In this study apart from the initial Hai, F. I., Tessmer, K., Nguyen, L. N., Kang, J., Price, W. E. \& Nghiem, L. D. (2011). Removal of micropollutants by membrane bioreactor under temperature variation. Journal of Membrane Science, 383 (1-2), 144-151. 
412 stage, the EPS level was rather stable throughout operation under the temperature shifts 413 (Figure 5). On the other hand, the protein content of SMP showed significant increase at 414 operating temperatures lower or higher than $20^{\circ} \mathrm{C}$, with the significant increase observed 415 during operation under near-thermophilic $\left(45^{\circ} \mathrm{C}\right)$ conditions. Our observation regarding 416 variation of EPS and SMP levels with operating temperature is in good agreement with the 417 available literature reports. Zhang et al., [21] reported a relatively stable total EPS 418 concentration in sludge when MBR temperature was increased from $40{ }^{\circ} \mathrm{C}$ to $45{ }^{\circ} \mathrm{C}$. Al419 Amri et al. [20] observed relatively steady level of EPS until $55^{\circ} \mathrm{C}$. Furthermore, in line with 420 our observation, available reports suggest that deflocculation of MBR sludge and heightened 421 SMP release occurs both during operation under low (e.g. $13{ }^{\circ} \mathrm{C}$ ) [42] and high (e.g. 422 thermophilic) [20-21] temperature conditions.

\section{[Figure 5]}

424 An interesting similarity of variation of TMP and SMP levels with changes in MBR operating 425 temperature was discernible in this study. TMP remained stable for the first three weeks of 426 operation $\left(20^{\circ} \mathrm{C}\right)$ and started to increase when the reactor temperature was reduced to $10{ }^{\circ} \mathrm{C}$ 427 (Figure 6). This suggests that the heightened level of SMP initiated fouling and once fouling 428 had occurred, TMP continued to rise gradually even when the temperature was returned to 20 $429{ }^{\circ} \mathrm{C}$. TMP increase at a more accelerated rate was observed during operation at higher 430 temperatures, especially $45{ }^{\circ} \mathrm{C}$, possibly due to the further increased level of SMP. Our 431 results demonstrate a significant correlation of TMP rise with that of SMP (protein) and 432 suggest that while more aggravated fouling may occur during operations both below or over $43320{ }^{\circ} \mathrm{C}$, fouling can become very severe at the higher temperatures $\left(35{ }^{\circ} \mathrm{C}\right.$ and $\left.45{ }^{\circ} \mathrm{C}\right)$. 434 Previously Abenayaka et al., [43] linked membrane fouling under thermophilic condition to 435 higher protein generation within the reactors. In fact while SMP level can increase either 436 under or beyond $20{ }^{\circ} \mathrm{C}$, higher viscosity of sludge at low temperature promotes particle 437 deposition on membrane, and hence, physically reversible fouling dominates at low 438 temperature (e.g. $13{ }^{\circ} \mathrm{C}$ ) $[42,44]$, while physically irreversible fouling can be expected to 439 develop more rapidly in the high-temperature period [44]. This may explain the observed 440 sharp increase in TMP during operation under $45^{\circ} \mathrm{C}$ in this study.

\section{[Figure 6]}

Hai, F. I., Tessmer, K., Nguyen, L. N., Kang, J., Price, W. E. \& Nghiem, L. D. (2011). Removal of micropollutants by membrane bioreactor under temperature variation. Journal of Membrane Science, 383 (1-2), 144-151. 


\section{Conclusion}

443 In this study, variation in operating temperature $\left(10-45^{\circ} \mathrm{C}\right)$ exerted considerable effects on

444 biological activity of MBR sludge which was initially acclimatized at $20{ }^{\circ} \mathrm{C}$. Variations were

445 observed regarding several basic parameters including TOC and TN removal, sludge 446 generation and EPS and SMP production. In particular, the operation at $45{ }^{\circ} \mathrm{C}$ was 447 characterized with significant drops in TOC and TN removal efficiency and MLSS 448 concentration and heightened levels of SMP in the mixed liquor. Increased level of SMP both 449 during temperature downshift and upshifts appeared to trigger accelerated TMP buildup. 450 Despite significant variations in the bioreactor supernatant, TOC and TN concentrations in 451 the membrane permeate remained relatively stable, possibly due to additional retention on 452 membrane cake layer. The observed removal efficiency at $20{ }^{\circ} \mathrm{C}$ of the micropollutants 453 selected in this study could be explained via a unique approach considering hydrophobicity 454 (Log D) and presence of electron withdrawing and donating functional groups. With a few 455 exception, operation at $45{ }^{\circ} \mathrm{C}$ clearly exerted detrimental effects on the removal efficiency of 456 the micropollutants selected in this study. The removal of most hydrophobic compounds (Log $457 \mathrm{D}>3.2$ ) was stable during operations under the temperature range of $10-35{ }^{\circ} \mathrm{C}$. On the 458 other hand, for the less hydrophobic compounds ( $\log \mathrm{D}<3.2)$ a comparatively more 459 pronounced variation between removals in the lower temperature regimes $\left(10-35{ }^{\circ} \mathrm{C}\right)$ was 460 observed. Lower and more variable removal efficiency at $10{ }^{\circ} \mathrm{C}$ was observed for certain 461 hydrophilic compounds which have been reported to be moderately recalcitrant to MBR 462 treatment. This study provides unique insight into the effect of dynamic short term (e.g., 463 diurnal) temperature variation on micropollutant removal by MBR treatment. However, 464 further studies under prolonged microbial acclimatization under each temperature regime 465 would be essential to know the steady state removal performance under mesophilic or 466 thermophilic temperature regimes.

\section{Acknowledgements}

468 Zenon Environment (Toronto, Ontario, Canada) is thanked for the provision of membrane 469 samples.

\section{$470 \quad 6 \quad$ References}

471 [1] A. Santos, W. Ma, S.J. Judd, Membrane bioreactors: Two decades of research and 472 implementation, Desalination, 273 (2011) 148-154.

Hai, F. I., Tessmer, K., Nguyen, L. N., Kang, J., Price, W. E. \& Nghiem, L. D. (2011). Removal of micropollutants by membrane bioreactor under temperature variation. Journal of Membrane Science, 383 (1-2), 144-151. 
473 [2] T. Melin, B. Jefferson, D. Bixio, C. Thoeye, W. De Wilde, J. De Koning, J. van der Graaf, 474 T. Wintgens, Membrane bioreactor technology for wastewater treatment and reuse, 475 Desalination, 187 (2006) 271-282.

476 [3] B. Kasprzyk-Hordern, R.M. Dinsdale, A.J. Guwy, The removal of pharmaceuticals, 477 personal care products, endocrine disruptors and illicit drugs during wastewater treatment and 478 its impact on the quality of receiving waters, Water Research, 43 (2009) 363-380.

479 [4] M. Cirja, P. Ivashechkin, A. Schäffer, P. Corvini, Factors affecting the removal of organic 480 micropollutants from wastewater in conventional treatment plants (CTP) and membrane 481 bioreactors (MBR), Reviews in Environmental Science and Biotechnology, 7 (2008) 61-78.

482 [5] M. Clara, B. Strenn, O. Gans, E. Martinez, N. Kreuzinger, H. Kroiss, Removal of selected 483 pharmaceuticals, fragrances and endocrine disrupting compounds in a membrane bioreactor 484 and conventional wastewater treatment plants, Water Research, 39 (2005) 4797-4807.

485 [6] A. Joss, E. Keller, A.C. Alder, A. Göbel, C.S. McArdell, T. Ternes, H. Siegrist, Removal 486 of pharmaceuticals and fragrances in biological wastewater treatment, Water Research, 39 487 (2005) 3139-3152.

488 [7] N. Tadkaew, F.I. Hai, J.A. McDonald, S.J. Khan, L.D. Nghiem, Removal of trace 489 organics by MBR treatment: The role of molecular properties, Water Research, 45 (2011) $490 \quad 2439-2451$.

491 [8] T. Urase, C. Kagawa, T. Kikuta, Factors affecting removal of pharmaceutical substances 492 and estrogens in membrane separation bioreactors, Desalination, 178 (2005) 107-113.

493 [9] S. Weiss, T. Reemtsma, Membrane bioreactors for municipal wastewater treatment - A 494 viable option to reduce the amount of polar pollutants discharged into surface waters?, Water 495 Research, 42 (2008) 3837-3847.

496 [10] F.I. Hai, N. Tadkaew, J.A. McDonald, S.J. Khan, L.D. Nghiem, Is halogen content the 497 most important factor in the removal of halogenated trace organics by MBR treatment?, 498 Bioresource Technology, 102 (2011) 6299-6303.

Hai, F. I., Tessmer, K., Nguyen, L. N., Kang, J., Price, W. E. \& Nghiem, L. D. (2011). Removal of micropollutants by membrane bioreactor under temperature variation. Journal of Membrane Science, 383 (1-2), 144-151. 
499 [11] X. Li, F.I. Hai, L.D. Nghiem, Simultaneous activated carbon adsorption within a 500 membrane bioreactor for an enhanced micropollutant removal, Bioresource Technology, 102 $501 \quad$ (2011) 5319-5324.

502 [12] N. Tadkaew, M. Sivakumar, S.J. Khan, J.A. McDonald, L.D. Nghiem, Effect of mixed 503 liquor $\mathrm{pH}$ on the removal of trace organic contaminants in a membrane bioreactor, 504 Bioresource Technology, 101 (2010) 1494-1500.

505 [13] F. Morgan-Sagastume, D.G. Allen, Effects of temperature transient conditions on 506 aerobic biological treatment of wastewater, Water Research, 37 (2003) 3590-3601.

507 [14] P.B. Price, T. Sowers, Temperature dependence of metabolic rates for microbial growth, 508 maintenance, and survival, Proceedings of the National Academy of Sciences of the United 509 States of America, 101 (2004) 4631-4636.

510 [15] Q. Sui, J. Huang, S. Deng, W. Chen, G. Yu, Seasonal variation in the occurrence and 511 removal of pharmaceuticals and personal care products in different biological wastewater 512 treatment processes, Environmental Science and Technology, 45 (2011) 3341-3348.

513 [16] N.M. Vieno, T. Tuhkanen, L. Kronberg, Seasonal Variation in the Occurrence of 514 Pharmaceuticals in Effluents from a Sewage Treatment Plant and in the Recipient Water, 515 Environmental Science \& Technology, 39 (2005) 8220-8226.

516 [17] S. Suarez, J.M. Lema, F. Omil, Removal of Pharmaceutical and Personal Care Products 517 (PPCPs) under nitrifying and denitrifying conditions, Water Research, 44 (2010) 3214-3224.

518 [18] T. Tanghe, G. Devriese, W. Verstraete, Nonylphenol degradation in lab scale activated 519 sludge units is temperature dependent, Water Research, 32 (1998) 2889-2896.

520 [19] H. Zilouei, A. Soares, M. Murto, B. Guieysse, B. Mattiasson, Influence of temperature 521 on process efficiency and microbial community response during the biological removal of 522 chlorophenols in a packed-bed bioreactor, Applied Microbiology and Biotechnology, 72 523 (2006) 591-599.

524 [20] A. Al-Amri, M.R. Salim, A. Aris, The effect of different temperatures and fluxes on the 525 performance of membrane bioreactor treating synthetic-municipal wastewater, Desalination, 526259 (2010) 111-119.

Hai, F. I., Tessmer, K., Nguyen, L. N., Kang, J., Price, W. E. \& Nghiem, L. D. (2011). Removal of micropollutants by membrane bioreactor under temperature variation. Journal of Membrane Science, 383 (1-2), 144-151. 
527 [21] S. Zhang, F. Yang, Y. Liu, X. Zhang, Y. Yamada, K. Furukawa, Performance of a 528 metallic membrane bioreactor treating simulated distillery wastewater at temperatures of 30 529 to $45^{\circ} \mathrm{C}$, Desalination, 194 (2006) 146-155.

530 [22] J.H. Al-rifai, Performance of water recycling technologies, in: PhD Thesis, School of 531 Civil, Mining \& Environmental Engineering - Faculty of Engineering, University of 532 Wollongong, Wollongong, 2008.

533 [23] G. Gatidou, N.S. Thomaidis, A.S. Stasinakis, T.D. Lekkas, Simultaneous determination 534 of the endocrine disrupting compounds nonylphenol, nonylphenol ethoxylates, triclosan and 535 bisphenol A in wastewater and sewage sludge by gas chromatography-mass spectrometry, 536 Journal of Chromatography A, 1138 (2007) 32-41.

537 [24] A.D. Eaton, L.S. Clescerl, E.W. Rice, A.E. Greenberg, Standard Methods for 538 Examination of Water \& Wastewater $21^{\text {st }}$ ed., American Public Health Association 2005.

539 [25] R.S. Hanson, J.A. Philips, Chemical composition, in: P. Gerhardt (Ed.) Manual of 540 methods for general bacteriology, ASM, Washington DC, 1981, pp. 328-364.

541 [26] N. Sundaresan, L. Philip, Performance evaluation of various aerobic biological systems 542 for the treatment of domestic wastewater at low temperatures, Water Science and 543 Technology, 58 (2008) 819-830.

544 [27] M.J.M. Wells, Log D-OW: Key to understanding and regulating wastewater-derived 545 contaminants, Environmental Chemistry, 3 (2006) 439-449.

546 [28] J. Radjenovic, M. Petrovic, D. Barceló, Analysis of pharmaceuticals in wastewater and 547 removal using a membrane bioreactor, Analytical and Bioanalytical Chemistry, 387 (2007) $548 \quad 1365-1377$.

549 [29] E. Sahar, I. David, Y. Gelman, H. Chikurel, A. Aharoni, R. Messalem, A. Brenner, The 550 use of RO to remove emerging micropollutants following CAS/UF or MBR treatment of 551 municipal wastewater, Desalination, 273 (2011) 142-147.

552 [30] S. Beier, S. Köster, K. Veltmann, H.F. Schröder, J. Pinnekamp, Treatment of hospital 553 wastewater effluent by nanofiltration and reverse osmosis, Water Science and Technology, $554 \quad 61(2010) 1691-1698$.

Hai, F. I., Tessmer, K., Nguyen, L. N., Kang, J., Price, W. E. \& Nghiem, L. D. (2011). Removal of micropollutants by membrane bioreactor under temperature variation. Journal of Membrane Science, 383 (1-2), 144-151. 
555 [31] V. Matamoros, J.M. Bayona, Elimination of Pharmaceuticals and Personal Care 556 Products in Subsurface Flow Constructed Wetlands, Environmental Science \& Technology, $557 \quad 40(2006) 5811-5816$.

558 [32] C. Visvanathan, L.N. Thu, V. Jegatheesan, J. Anotai, Biodegradation of 559 pentachlorophenol in a membrane bioreactor, Desalination, 183 (2005) 455-464.

560 [33] Y. Suzuki, T. Maruyama, Fate of natural estrogens in batch mixing experiments using 561 municipal sewage and activated sludge, Water Research, 40 (2006) 1061-1069.

562 [34] S. Zuehlke, U. Duennbier, B. Lesjean, R. Gnirss, H. Buisson, Long-term comparison of 563 trace organics of removal performances between conventional and membrane activated 564 sludge processes, Water Environment Research, 78 (2006) 2480-2486.

565 [35] V. Gabet-Giraud, C. Miege, J.M. Choubert, S.M. Ruel, M. Coquery, Occurrence and 566 removal of estrogens and beta blockers by various processes in wastewater treatment plants, 567 Science of the Total Environment, 408 (2010) 4257-4269.

568 [36] L. Bertin, S. Capodicasa, F. Occulti, S. Girotti, L. Marchetti, F. Fava, Microbial 569 processes associated to the decontamination and detoxification of a polluted activated sludge 570 during its anaerobic stabilization, Water Research, 41 (2007) 2407-2416.

571 [37] T. Benabdallah El-Hadj, J. Dosta, J. Mata-Alvarez, Biodegradation of PAH and DEHP 572 micro-pollutants in mesophilic and thermophilic anaerobic sewage sludge digestion, in: 573 Water Science and Technology, 2006, pp. 99-107.

574 [38] T.M. LaPara, C.H. Nakatsu, L.M. Pantea, J.E. Alleman, Aerobic Biological Treatment of 575 a Pharmaceutical Wastewater: : Effect of Temperature on COD Removal and Bacterial 576 Community Development, Water Research, 35 (2001) 4417-4425.

577 [39] T.E.M. ten Hulscher, G. Cornelissen, Effect of temperature on sorption equilibrium and 578 sorption kinetics of organic micropollutants - a review, Chemosphere, 32 (1996) 609-626.

579 [40] S. Castiglioni, R. Bagnati, R. Fanelli, F. Pomati, D. Calamari, E. Zuccato, Removal of 580 pharmaceuticals in sewage treatment plants in Italy, Environ. Sci. Technol., 40 (2006) 357581363.

Hai, F. I., Tessmer, K., Nguyen, L. N., Kang, J., Price, W. E. \& Nghiem, L. D. (2011). Removal of micropollutants by membrane bioreactor under temperature variation. Journal of Membrane Science, 383 (1-2), 144-151. 
582 [41] J.C.T. Dias, R.P. Rezende, C.M. Silva, V.R. Linardi, Biological treatment of kraft pulp 583 mill foul condensates at high temperatures using a membrane bioreactor, Process 584 Biochemistry, 40 (2005) 1125-1129.

585 [42] T. Jiang, M.D. Kennedy, B.F. Guinzbourg, P.A. Vanrolleghem, J.C. Schippers, 586 Optimising the operation of a MBR pilot plant by quantitative analysis of the membrane 587 fouling mechanism, Water Science \& Technology, 51 (2005) 19-25.

588 [43] A. Abeynayaka, C. Visvanathan, Performance comparison of mesophilic and 589 thermophilic aerobic sidestream membrane bioreactors treating high strength wastewater, 590 Bioresource Technology, 102 (2011) 5345-5352.

591 [44] T. Miyoshi, T. Tsuyuhara, R. Ogyu, K. Kimura, Y. Watanabe, Seasonal variation in 592 membrane fouling in membrane bioreactors (MBRs) treating municipal wastewater, Water 593 Research, 43 (2009) 5109-5118. 


\section{LIST OF FIGURES}

596 Figure 1: Variation of TOC (a) and TN (b) concentration in mixed liquor supernatant and

597 membrane-permeate along with controlled temperature shifts.

598 Figure 2: Removal of micropollutants at the temperature of initial acclimatization $\left(20{ }^{\circ} \mathrm{C}\right)$.

599 Error bars represent the standard deviation of seven measurements.

600 Figure 3: Removal of micropollutants during operation with controlled temperature shifts.

601 The MBR was subject to five distinct phases wherein the temperature of the mixed liquor was 602 maintained in the following order: $20,10,20,35$ and $45^{\circ} \mathrm{C}$. The $45^{\circ} \mathrm{C}$ phase was maintained 603 for two weeks, while each of the other phases lasted for three weeks. Error bars represent the 604 standard deviation of seven and four measurements, in case $20{ }^{\circ} \mathrm{C}$ and other temperature 605 values, respectively.

606 Figure 4: Effect of operating temperature on the MLSS and MLVSS concentration.

607 Figure 5: Variation of EPS (a) and SMP (b) content in mixed liquor as a function of 608 operating temperature.

609 Figure 6: Variation of transmembrane pressure (TMP) during operation under different 610 temperature regime. 

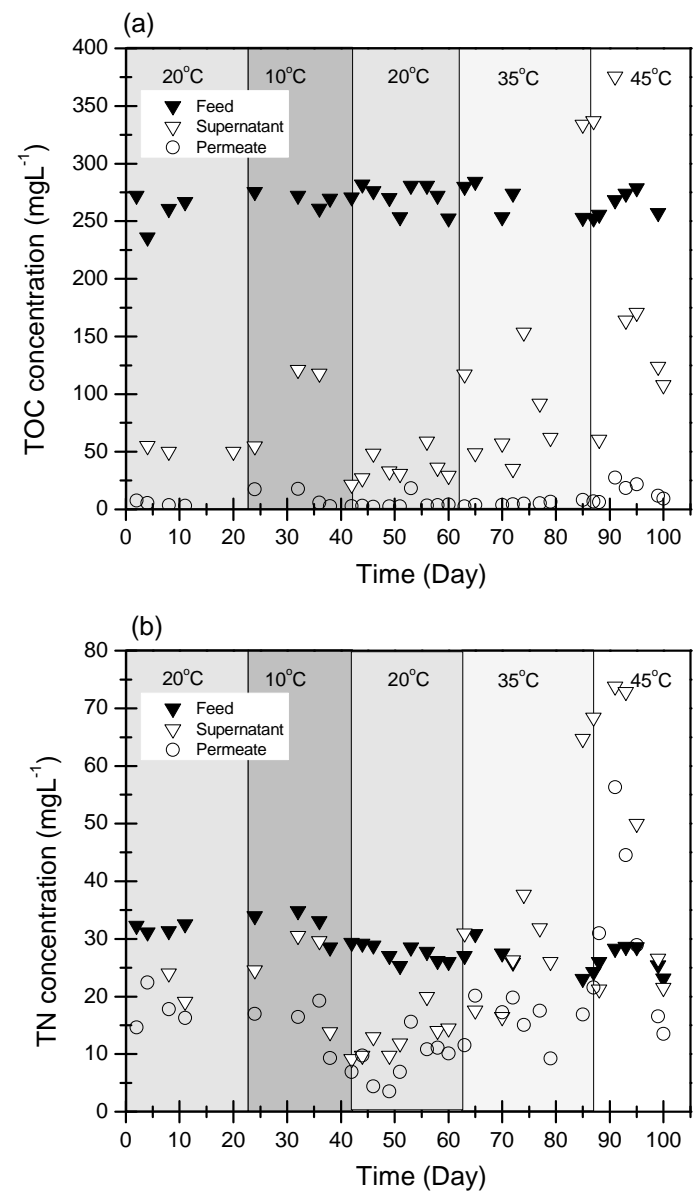

$610 \quad$ Figure 1 


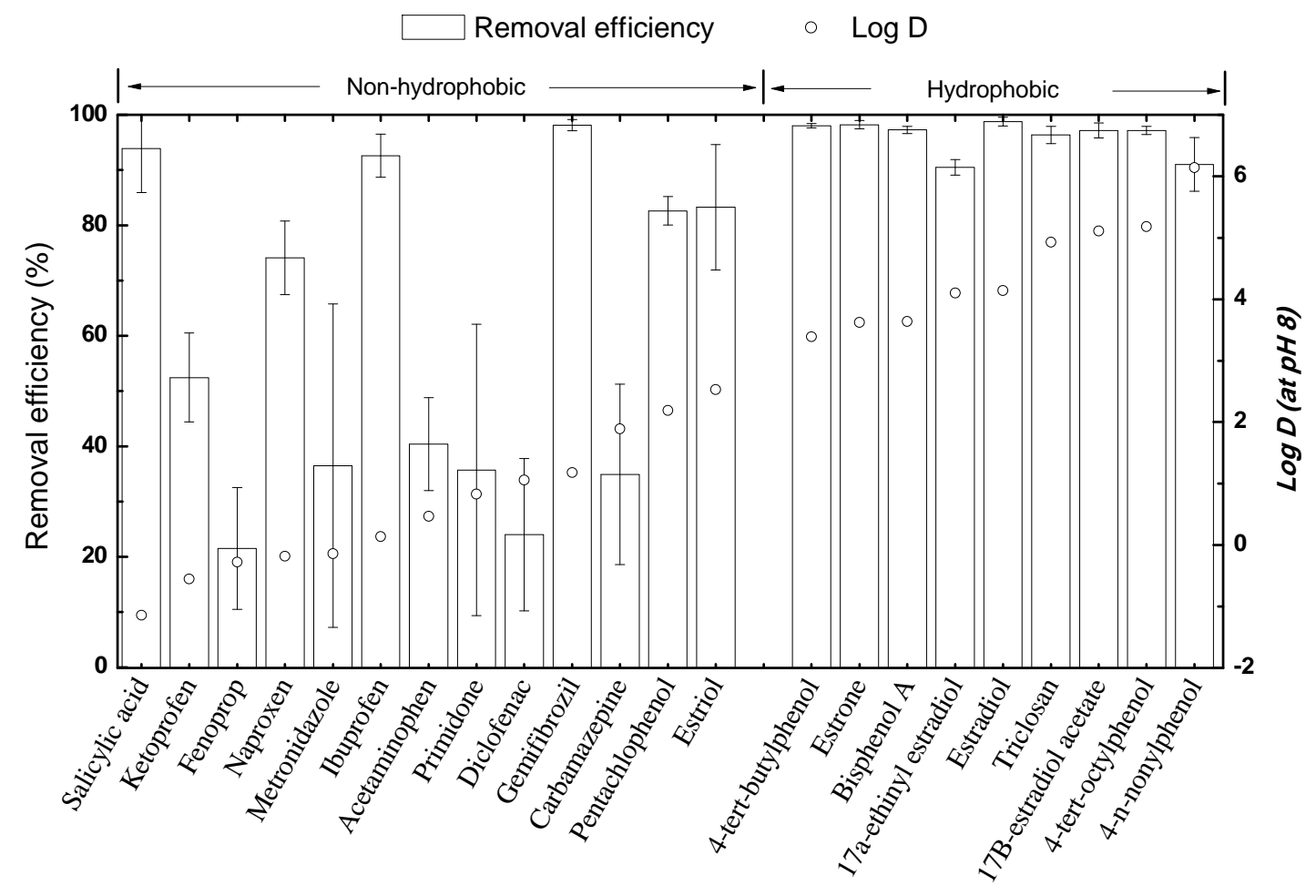

611

612 Figure 2 
$\square 10{ }^{\circ} \mathrm{C} \quad$ VII $20{ }^{\circ} \mathrm{C}$

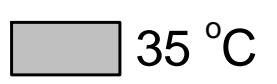

$\square 45^{\circ} \mathrm{C}$

614

615

616

617

618

619

620

621

622

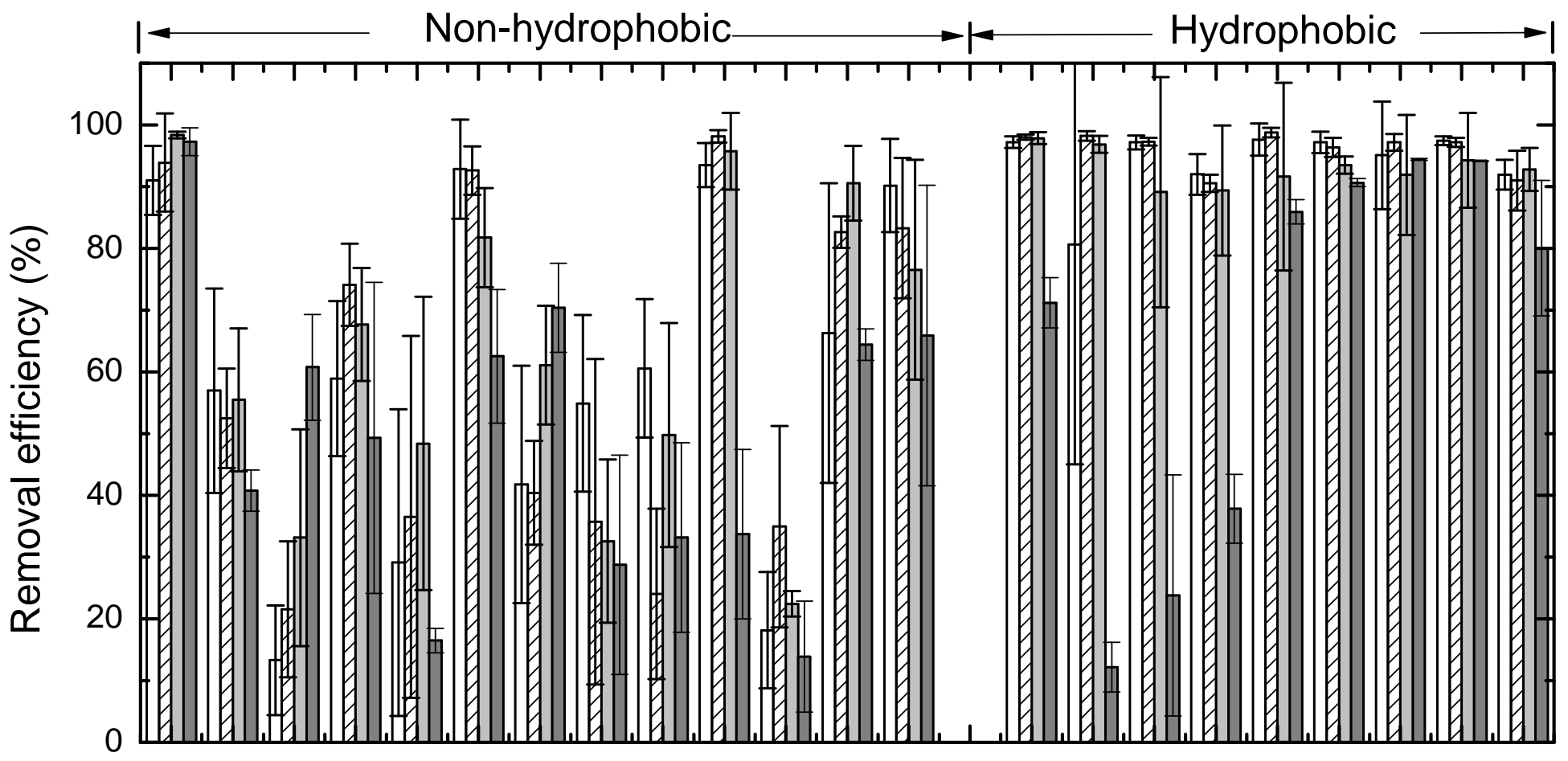

623

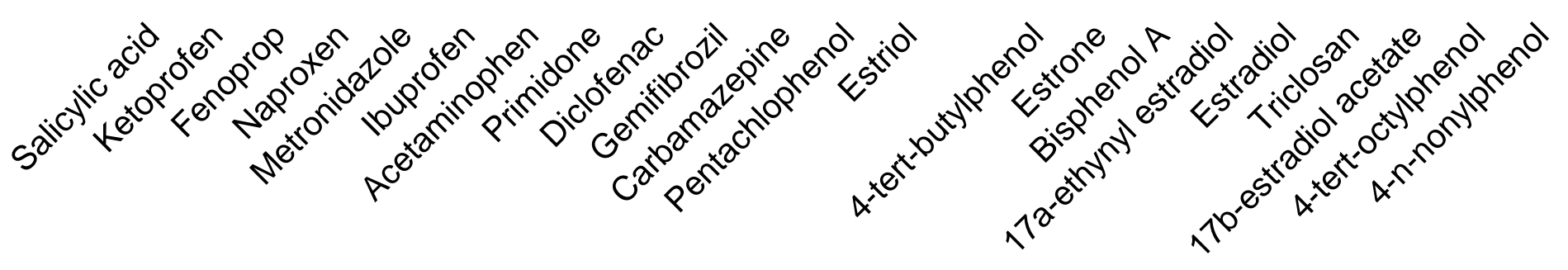

$624 \quad$ Figure 3 


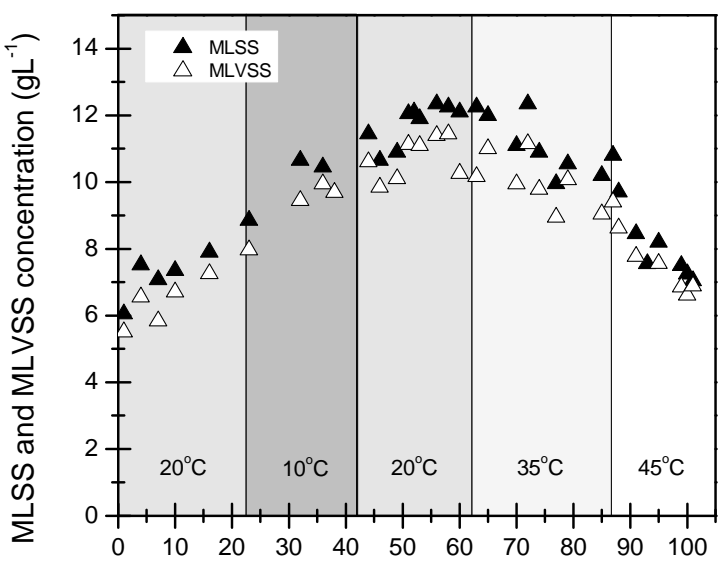

625

day of operation

626 Figure 4

627 

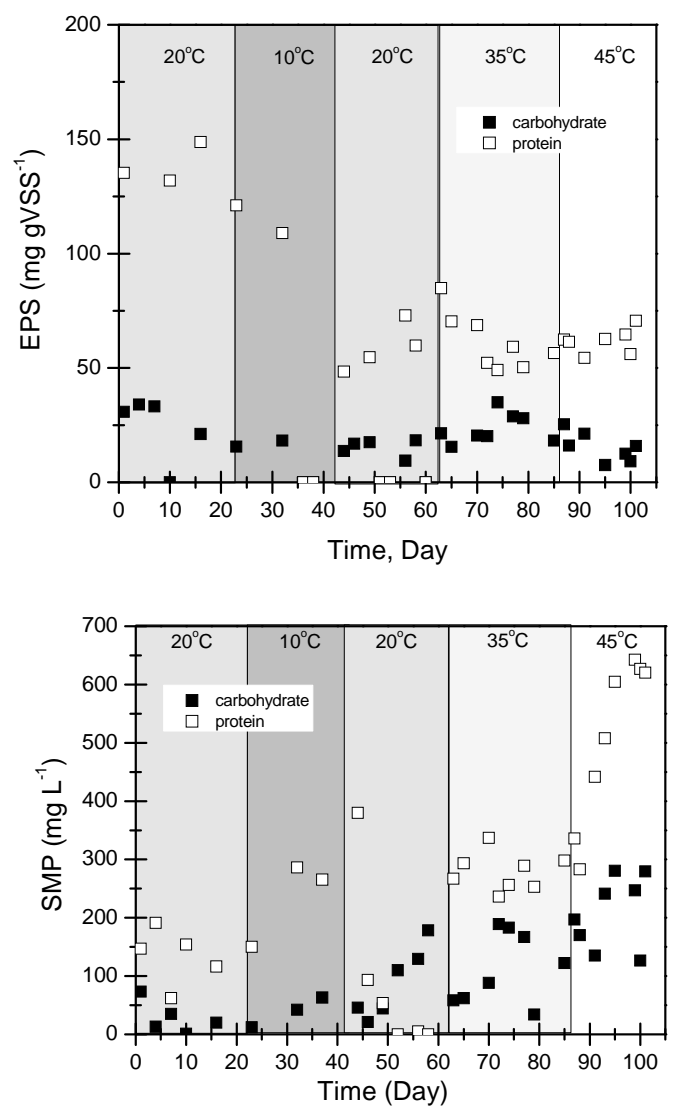

$629 \quad$ Figure 5

630 


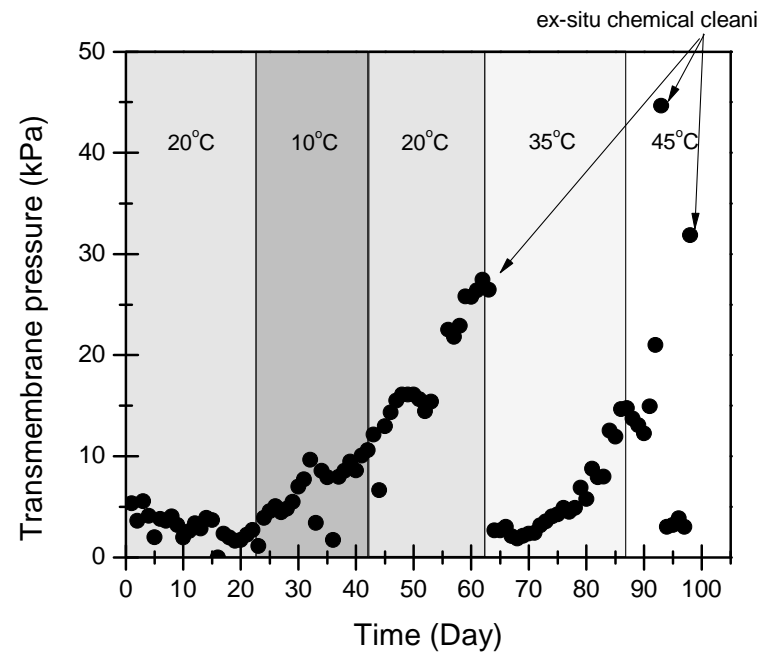

631

$632 \quad$ Figure 6 


\title{
Removal of micropollutants by membrane bioreactor under temperature variation
}

\author{
Faisal I. Hai ${ }^{1}$, Karin Tessmer ${ }^{1}$, Luong N. Nguyen ${ }^{1}$, Jinguo Kang ${ }^{1,2}$, William E. Price ${ }^{2}$, and \\ Long D. Nghiem ${ }^{1, *}$ \\ ${ }^{1}$ Strategic Water Infrastructure Laboratory \\ School of Civil, Mining and Environmental Engineering \\ University of Wollongong, NSW 2522, Australia \\ ${ }^{2}$ Strategic Water Infrastructure Laboratory \\ School of Chemistry \\ University of Wollongong, NSW 2522, Australia
}

12

13 * Corresponding author: Long Duc Nghiem, Email: longn@uow.edu.au, Ph +61 242214590 
Table S1: Physicochemical properties of the selected micropollutants.

\begin{tabular}{|c|c|c|c|c|c|c|c|c|}
\hline Category & Compound & CAS number & $\begin{array}{l}\text { Molecular } \\
\text { weight } \\
(\mathrm{g} / \mathrm{mol})\end{array}$ & $\log \mathrm{K}_{\mathrm{OW}}{ }^{\mathrm{a}}$ & $\begin{array}{c}\log \mathrm{D} \text { at } \\
\mathrm{pH} 8^{\mathrm{a}}\end{array}$ & $\begin{array}{l}\text { Dissociation } \\
\text { constant } \\
(\mathrm{pKa})^{\mathrm{a}}\end{array}$ & $\begin{array}{l}\text { Water } \\
\text { solubility } \\
(\mathrm{mg} / \mathrm{L})^{\mathrm{b}}\end{array}$ & Structure of compounds \\
\hline \multirow{5}{*}{ 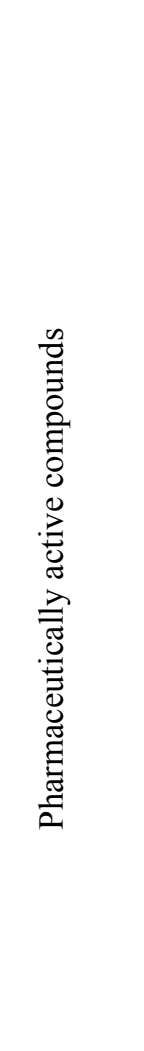 } & $\begin{array}{l}\text { Ibuprofen } \\
\left(\mathrm{C}_{13} \mathrm{H}_{18} \mathrm{O}_{2}\right)\end{array}$ & $15687-27-1$ & 206.28 & $3.50 \pm 0.23$ & 0.14 & $4.41 \pm 0.10$ & 21 & $\mathrm{CH}_{3}$ \\
\hline & $\begin{array}{c}\text { Acetaminophen } \\
\left(\mathrm{C}_{8} \mathrm{H}_{9} \mathrm{NO}_{2}\right)\end{array}$ & $103-90-2$ & 151.16 & $0.48 \pm 0.21$ & 0.47 & $\begin{array}{l}9.86 \pm 0.13 \\
1.72 \pm 0.50\end{array}$ & 14000 & \\
\hline & $\begin{array}{l}\text { Naproxen } \\
\left(\mathrm{C}_{14} \mathrm{H}_{14} \mathrm{O}_{3}\right)\end{array}$ & 22204-53-1 & 230.26 & $2.88 \pm 0.24$ & -0.18 & $4.84 \pm 0.30$ & 16 & \\
\hline & $\begin{array}{l}\text { Ketoprofen } \\
\left(\mathrm{C}_{16} \mathrm{H}_{14} \mathrm{O}_{3}\right)\end{array}$ & $22071-15-4$ & 254.28 & $2.91 \pm 0.33$ & -0.55 & $4.23 \pm 0.10$ & 16 & \\
\hline & $\begin{array}{c}\text { Diclofenac } \\
\left(\mathrm{C}_{14} \mathrm{H}_{11} \mathrm{Cl}_{2} \mathrm{NO}_{2}\right)\end{array}$ & $15307-86-5$ & 296.15 & $4.55 \pm 0.57$ & 1.06 & $\begin{array}{l}4.18 \pm 0.10 \\
-2.26 \pm 0.50\end{array}$ & 2.4 & \\
\hline
\end{tabular}




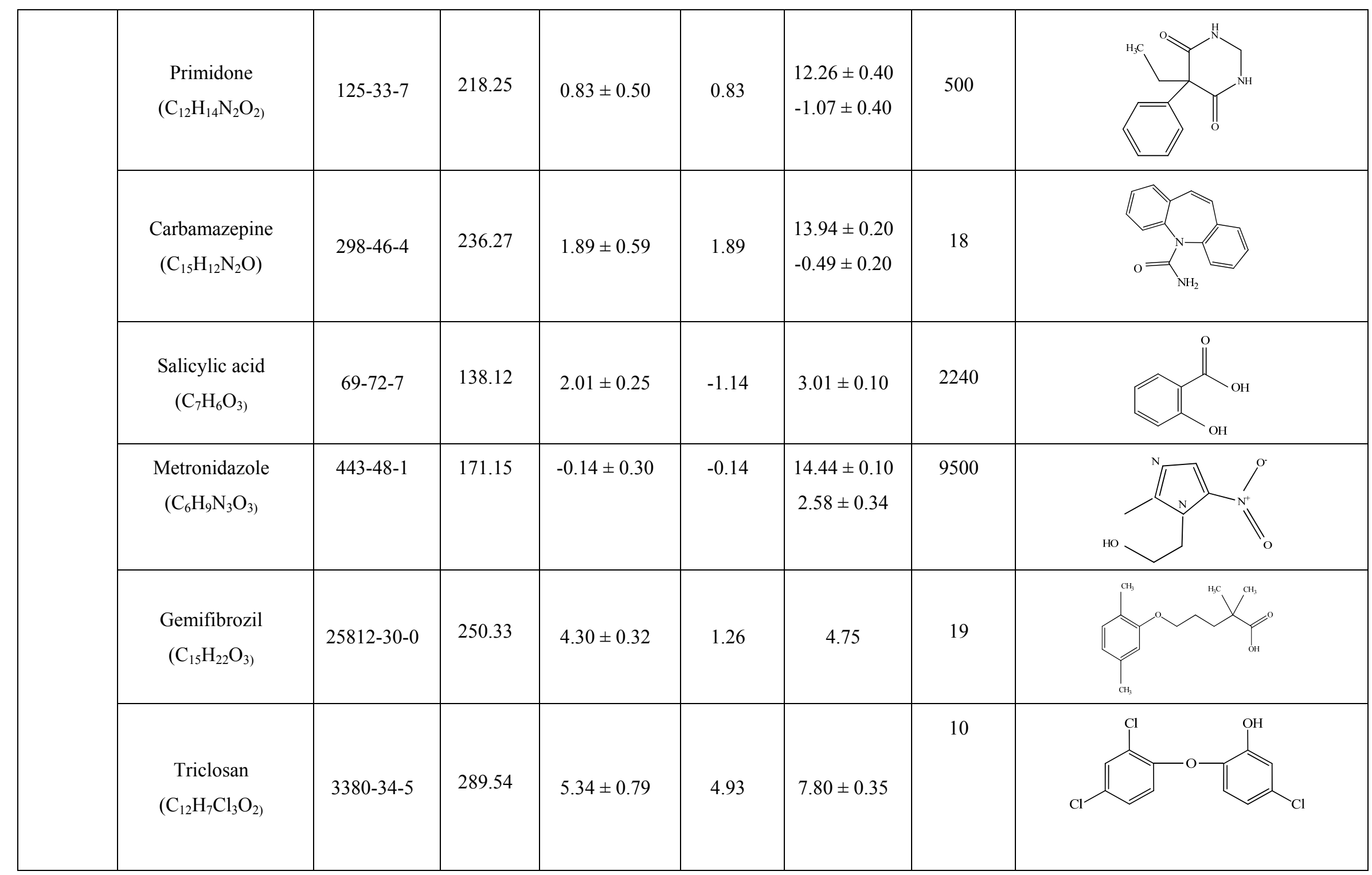




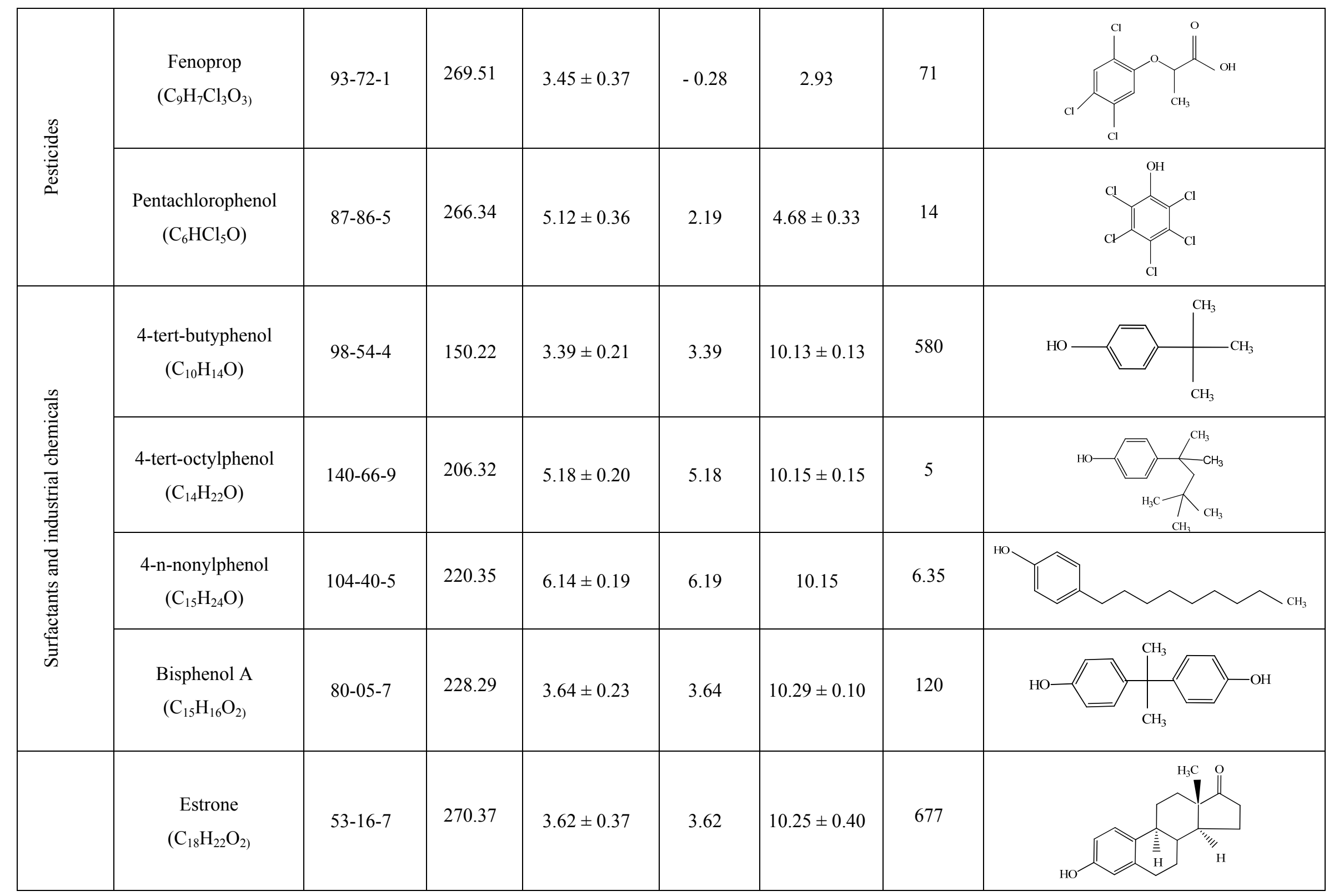




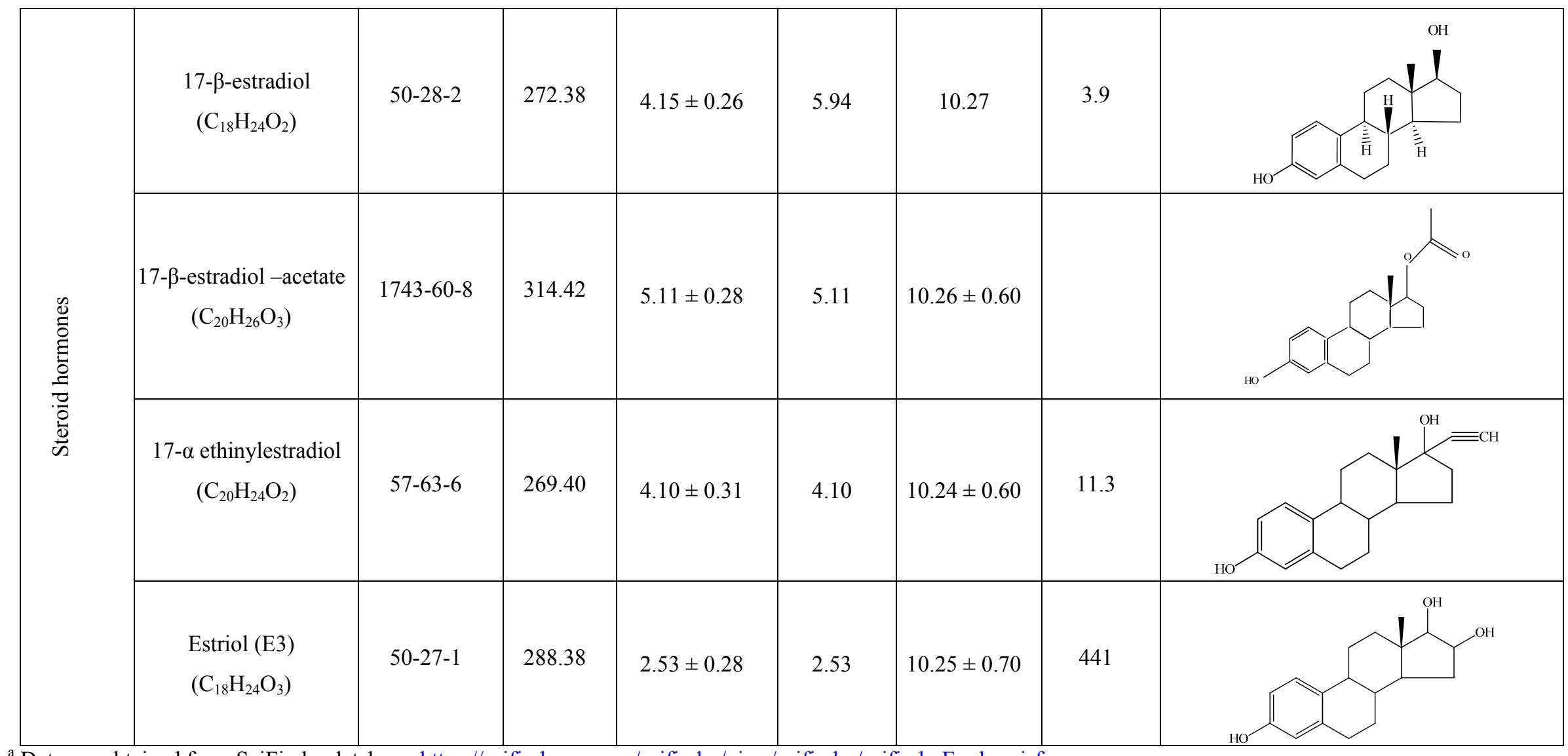

${ }^{a}$ Data are obtained from SciFinder database https://scifinder.cas.org/scifinder/view/scifinder/scifinderExplore.jsf

${ }^{\mathrm{b}}$ Water solubility are obtained form http://chem.sis.nlm.nih.gov/chemidplus/ 


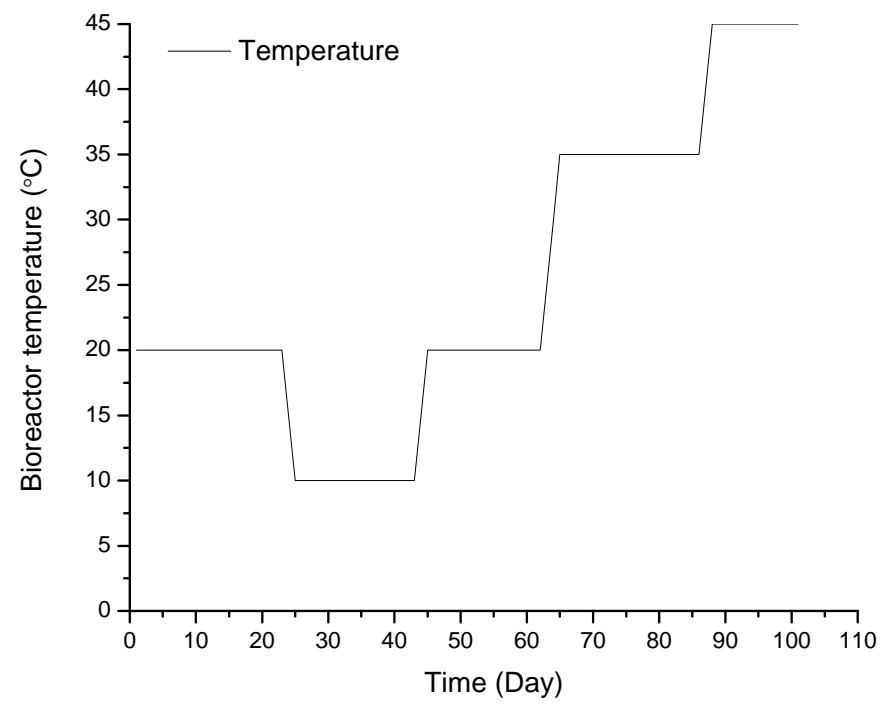

Figure S2: Controlled variation in the operating temperature of the MBR. 
Table S3: Limit of detection of each compound during GC-MS analysis and average influent and permeate concentrations during operation under $20^{\circ} \mathrm{C}$ as an example.

\begin{tabular}{|c|c|c|c|c|}
\hline No. & Compound & $\begin{array}{c}\text { Detection Limit } \\
(\mathrm{ng} / \mathrm{L})\end{array}$ & $\begin{array}{l}\text { Average measured influent } \\
\text { concentration }(\mathrm{ng} / \mathrm{L})\end{array}$ & $\begin{array}{l}\text { Average permeate } \\
\text { concentration }(\mathrm{ng} / \mathrm{L})\end{array}$ \\
\hline 1 & 4-tert-butylphenol & 1 & 3900 & 80 \\
\hline 2 & Salicylic acid & 1 & 3100 & 190 \\
\hline 3 & Ibuprofen & 20 & 3900 & 290 \\
\hline 4 & Acetaminophen & 20 & 2100 & 1240 \\
\hline 5 & Metronidazole & 20 & 750 & 470 \\
\hline 6 & Primidone & 10 & 3100 & 2000 \\
\hline 7 & Fenoprop & 20 & 4770 & 3740 \\
\hline 8 & Pentachlorophenol & 1 & 4450 & 770 \\
\hline 9 & Gemifibrozil & 1 & 4670 & 90 \\
\hline 10 & Naproxen & 1 & 4700 & 1220 \\
\hline 11 & Ketoprofen & 20 & 3450 & 1640 \\
\hline 12 & Carbamazepine & 10 & 4450 & 2800 \\
\hline 13 & Diclofenac & 5 & 2380 & 1800 \\
\hline 14 & Triclosan & 1 & 4700 & 170 \\
\hline 15 & 4-tert-octylphenol & 1 & 4000 & 110 \\
\hline 16 & 4-n-nonylphenol & 10 & 3190 & 290 \\
\hline 17 & Bisphenol A & 1 & 4680 & 130 \\
\hline 18 & Estrone & 5 & 2620 & 50 \\
\hline 19 & $17-\beta$-estradiol & 5 & 2840 & 35 \\
\hline 20 & 17 - $\beta$-estradiol -acetate & 5 & 2690 & 80 \\
\hline 21 & 17- $\alpha$ ethinylestradiol & 10 & 2730 & 260 \\
\hline 22 & Estriol & 10 & 1200 & 200 \\
\hline I.S. & Bisphenol A-d $d_{16}$ & 1 & & \\
\hline
\end{tabular}

I.S: Internal standard 